\title{
The Crescent and the Dagger: Representations of the Moorish Other during the Spanish Civil War
}

\author{
ELISABETH BOLORINOS ALLARD \\ University of Edinburgh
}

\begin{abstract}
The figure of the Moor has long been central to the Spanish collective imagination. From the Reconquista to the nineteenth and twentieth century colonial campaigns in Morocco, maurophilial and maurophobic representations of the Moor have circulated in Spanish culture. During the Spanish Civil War, the figure of the Moor was revived when the Nationalist insurgents employed native Moroccan troops in their fight against Spanish Republicans. This article examines different forms of Republican and Nationalist discourse on the Moorish Other and the relationship between self-representations of Spanish identity and representations of the Moor. It argues that discourse on the Moorish Other did not primarily serve the purpose of representing the Moroccan soldier, but rather of representing conflicting visions of the Spanish nation. Nationalist representations of the Moor served as a mirror for the Nationalists, reflecting and affirming their self-imagined identity as a strong militaristic nation with an imperial destiny, while Republican representations served as a window through which Republicans witnessed, and set themselves apart from, the betrayal and brutality of the Nationalists.
\end{abstract}

\section{I}

'Solo desde Marruecos se aprecia España de cuerpo entero en su pasado, en su presente, y en su porvenir'.

Ramón Serrano Suñer, $1939 .{ }^{1}$

Just after dawn on 18 July 1936, over 1,200 years after Tariq ibn Ziyad and an army of Berber warriors crossed the strait of Gibraltar and began the Muslim conquest of Spain, ${ }^{2}$ a small group of Moroccan soldiers arrived on Spanish soil to wage war again on the inhabitants of the Iberian peninsula. However, this time they were not an army of foreign invaders but colonial subjects commanded by Spanish generals who had staged a military uprising against the government of the Second Republic. Over the course of the civil war that would ensue, nearly 80,000 Moroccan troops were deployed to fight in Spain for the right-wing Nationalist forces against Republican forces. $^{3}$ The return of the Moors would leave a dramatic imprint on the collective psyche of the Spanish nation. 1941), 8

${ }^{1}$ Tomás García Figueras, Marruecos: La acción de España en el norte de África (Madrid: Fe, 2009), 7.

${ }^{2}$ Matthew Carr, Blood and Faith: The Purging of Muslim Spain (London: Hurst \& Company, (Oxford: Oxford University Press, 2002), 312. 
The figure of el moro, from the Latin mauri, or maurusci, the Roman term for the Berbers of North Africa, ${ }^{4}$ is central to the Spanish imagination. Spanish philosopher Manuel García Morente wrote, 'las fuerzas opuestas del moro y el cristiano dominan el horizonte de la vida de España'. After the Reconquest of Granada in 1492, Spanish national identity was forged in opposition to the Moorish Other. To homogenize a population that had long been defined by cultural and religious pluralism, the Catholic monarchs Isabel and Ferdinand created the myth of the crusade, where Christian Iberians had battled Muslim invaders for eight hundred years, ultimately emerging victorious in Granada. Thus Islam was portrayed as the violent antithesis to Christianity and Muslims were imagined as subhuman barbarians, in the words of Thomas Aquinas, 'beastlike men who dwelt in the wilds.' 6

The Spanish occupation of Northern Morocco beginning in 1909 revived the character of el moro in the national narrative. The area controlled by Spain consisted mostly of the Rif Mountains inhabited by Berber tribes that had long resisted the authority of the sultan and rebelled equally against Spanish colonial control. These tribesmen were among the most accomplished guerrilla fighters in the world, ${ }^{7}$ distinguished by their theatrical war cries and customs of mutilation, decapitation, and castration. In contrast, Spanish soldiers sent to fight in Morocco often had no battle experience and hardly any training. The colonial campaigns between 1909 and 1926 cost the lives of thousands of Spanish soldiers. Eight thousand men died in the 1921 Battle of Annual alone, ${ }^{8}$ where the Spanish military suffered a crushing defeat by Moroccan insurrectionary forces, partially due to the fact that Moroccans fighting with the Spanish army deserted and joined the enemy. In 1934, indigenous troops were brought to Spain to crush a miners' uprising in the Northern province of Asturias, where they pillaged and burned homes, executed prisoners, and raped and murdered civilians. These experiences shaped a new colonial representation of the Moorish Other. General Mola, who was to become a key nationalist military figure in the Spanish Civil War, captured this representation in his description of Berber warriors in the Revista de Tropas Coloniales in June 1924; 'especializados en el crimen y el pillaje y profesionales de la deserción [...] entonando intencionadas canciones sobre el valor que el cherif daría a nuestras cabezas puestas en la punta afilada de una bayoneta' ${ }^{9}$

These encounters with the Moorish Other, in this case the Moroccan, contributed to the formation and polarization of military and working class identities emerging in Spain at the beginning of the twentieth century. A military subculture developed among the radically traditionalist and anti-democratic officer class in Morocco, who came to be known as the Africanistas. Most of the conspirators of the July 1936 coup, officers such as Jose Sanjurjo, Emilio Mola, Manuel Goded, José Enrique Varela, and Francisco Franco, were Africanistas whose identification with their own narrative of Moroccan life alienated them from the culture of their homeland. ${ }^{10}$ On the other hand, the Spanish lower classes, too poor to avoid military conscription, strongly opposed the colonization of Morocco. In his memoir Forja de

\footnotetext{
${ }^{4}$ Carr, Blood and Faith, 7.

${ }^{5}$ Juan Goytisolo: Crónicas Sarracenas (Barcelona: Editorial Seix Barral, 1989), 49.

${ }^{6}$ Carr, Blood and Faith, 209.

${ }^{7}$ Balfour, Deadly Embrace, 20.

${ }^{8}$ María Rosa de Madariaga, Los Moros que trajo Franco: La intervención de tropas coloniales en la Guerra Civil (Barcelona: Ediciones Martínez Roca, 2002), 36.

9 Emilio Mola, 'Los Primeros Regulares: Notas de mis Memorias', Revista de Tropas Coloniales, Año 1, n. 6 (June 1924):3, http://hemerotecadigital.bne.es.

${ }^{10}$ Balfour, Deadly Embrace, 202.
} 
un Rebelde, Republican author and veteran of the Moroccan campaigns Arturo Barea remarked; 'para el pueblo español Marruecos no era más que un desierto de unas pocas palmeras solitarias, donde los soldaditos españoles eran brutalmente asesinados'. ${ }^{11}$ Likewise, the brutality of the military repression in Asturias became a symbol of working class oppression. When the Moroccan troops returned to Spain in 1936 they crossed not only a physical but also an imaginary frontier, not between Spain and the Moorish Other, but between Nationalist Spain and Republican Spain. During the civil war, representations of the Moor were inexorably linked to these conflicting visions of Spain.

This article examines the relationship between self-representations of Spanish identity and representations of the Moorish Other, and the ways in which the image of the Moor was employed in the construction of the boundaries of the Spanish nation during the civil war. It will argue that discourse on the Moorish Other did not serve the purpose of representing the Moroccan soldier, but rather of representing different and conflicting visions of the Spanish nation. Nationalist representations of the Moor served as a mirror for the Nationalists, reflecting and affirming their self-constructed identity as a strong militaristic nation with an imperial destiny, while Republican representations served as a window through which Republicans witnessed, and set themselves apart from, the betrayal and brutality of the Nationalist insurgents. Moro was the Orientalist term used for centuries to describe Muslims and used during the civil war to describe the Moroccan troops, so it will also be employed in this analysis.

\section{El moro guerrero}

When the military conspirators declared their insurrection against the Second Republic in July 1936 Spain was already divided along battle lines, with a wide range of left-wing groups supporting the Republic and a cluster of right-wing parties identifying with the cause of the insurrectionists. The central military element in the Nationalist offensive was the Army of Africa, the sole professional fighting force in the Spanish army. It consisted of the Foreign Legion ${ }^{12}$ and four Moroccan indigenous units: the military and indigenous police forces of the Mahkzen (Mehal-las and Mejaznias), the irregular auxiliary forces, the Sidi Ifni Tiradores, and the Regulares, ${ }^{13}$ indigenous infantry regiments established in 1911 'para ahorrar sangre nacional' ${ }^{14}$ in the colonial campaigns. It was the Army of Africa that would advance towards Madrid through the southern regions of Andalusia and Extremadura in July and August 1936. As a result, for many Republicans, the face of the enemy that they would first encounter was that of the Moor.

The image of the Moor as a fierce moro guerrero appeared in Republican and Nationalist discourse alike. Yet while the Nationalists glorified the martial qualities of the Moorish warrior, portraying the Moroccans as noble and courageous soldiers, the Republicans depicted them as cruel and bloodthirsty savages. The interactions between Republican and Nationalist forms of this representation provide an interesting case for analysis.

\footnotetext{
${ }^{11}$ Arturo Barea, La Ruta (Barcelona: Debolsillo, 2007), 63.

${ }^{12}$ Elite fighting force established in 1920 to fight in the Moroccan colonial campaigns, comprised mostly of Spanish soldiers despite its name.

${ }^{13}$ Balfour, Deadly Embrace, 271.

${ }^{14}$ Mola 'Los Primeros Regulares'.
} 
The arrival of the Regulares spread terror throughout Republican territory. The medieval association of Moors with cruelty and danger had long been embedded in Spanish culture in children's games and popular expressions such as 'moros en la costa' as a warning of danger. ${ }^{15}$ This traditional image was revived in the summer of 1936 as stories of Moroccan atrocities circulated in the press. When the Army of Africa entered the working class neighbourhood of San Julián in Seville on 20 July, Regulares forced men and women into the streets and bayoneted them to death. ${ }^{16}$ After capturing the city of Badajoz in August, Regulares and Legionnaires commanded by General Yagüe carried out the mass murder of civilians in the town bullring. They committed similar massacres in towns throughout the south of Spain. When Regulares entered Toledo at the end of September they shot wounded Republican prisoners in the hospital. ${ }^{17}$ Antonio Bahamonde, the propaganda minister in Nationalist Seville who escaped to Republican territory after witnessing the atrocities committed by the Nationalists, described the scene in Badajoz. He reported that the city plaza 'estaba cubierta de sangre que corría por las escaleras de la catedral' where the Regulares had broken in and stabbed to death the Republican civilians that were hiding there. ${ }^{18}$ His narrative describes how the Moors raped women before killing them, profaned the bodies of their victims, and burned down houses after looting them. ${ }^{19}$ American journalist John Whittaker watched the Moroccan officer of the Regulares, El Mizzian, hand over two female textile workers arrested by the army to be gang raped by his troops. ${ }^{20}$ Lina Odena, a legendary Republican militiawoman who committed suicide when captured by the Nationalists, was said to have killed herself rather than be turned over to the Moors. ${ }^{21}$

The depiction of Moroccans as savage warriors raping and pillaging their way through Spain prevailed in Republican discourse in the first three months of the war. Propaganda described them as beasts hunting Spaniards, 'desclavando vuestras puertas sedientos de sangre'. ${ }^{22}$ The memory of the encounter with the Moors in the colonial wars and in Asturias was often invoked. 'Son los mismos moros y legionarios de octubre 1934 [...] Los que cobraban 10 pesetas de 'gratificación' por cada brazo o cada cabeza de español', reported the front-line Republican newspaper Milicia Popular in October 1936, 'Hoy son esos mismos asesinos! Los que están aquí en España con las mismas intenciones [...] de aplastar la virilidad de nuestro pueblo'. ${ }^{23}$

There was a typically Orientalist obsession with the sexual aspect of the Regulares' encounter with Spain, as European masculine fears and fantasies were projected onto the image of the Moroccans as over-sexualized savages. A cartoon

${ }^{15}$ María Rosa de Madariaga, La Imagen del moro en la memoria colectiva del pueblo español y retorno del moro en la Guerra Civil de 1936', Revista internacional de sociología, ser.2, 46:4 (Oct./Dec. 1988), 575.

${ }^{16}$ Madariaga, Los Moros que trajo Franco, 254.

${ }^{17}$ Madariaga, Los Moros que trajo Franco, 254.

${ }^{18}$ Antonio Bahamonde y Sanchez de Castro, Un año con Queipo: memorias de un nacionalista (Barcelona: Ediciones Españolas, 1938), 116.

${ }^{19}$ Bahamonde, Un año con Queipo, 96.

${ }^{20}$ Balfour, Deadly Embrace, 293.

${ }^{21}$ Eloy Martín Corrales, 'Entre el moro violador y el moro seductor', in Antropología y antropólogos en Marruecos: Homenaje a David M.Hart. ed. Angeles Fernández Ramírez (Barcelona: Bellaterra, 2002), 231.

${ }^{22}$ Adolfo Sánchez Vázquez, 'Romance de moros' in Poesía de la Guerra Civil Española, ed. César de Vicente Hernando (Madrid: Akal Ediciones, 1994), 278.

23 'Los Mismos moros y legionarios y los mismos procedimientos', Milicia popular: Diario del $5^{\circ}$ Regimiento de Milicias Populares, no. 63 (07/10/1936): 1. 
published in the Madrid newspaper $L a$ Voz showed a racist caricature of a fat moro with big lips, a raised dagger in one hand and a baby in his arms. ${ }^{24}$ 'Por Andalucía y Extremadura', read the article below, 'los Regulares indígenas de oscura piel, saltones ojos, belfos bestiales y negras manos- Roban, violan, y matan- ¡No las olvidéis, españoles! ¡Son nuestras madres, nuestras mujeres, nuestras hijas’! ${ }^{25}$

Similarly, in a radio broadcast from Madrid, Communist politician Dolores Ibárruri, 'La Pasionaria,' denounced the acts of 'morisma salvaje, borracha de sensualidad, que se vierte en horrendas violaciones de nuestras muchachas en los pueblos que han sido hilados por la pezuña fascista'. ${ }^{26}$ The image of the feminine nation violated by a beastly enemy is typical of wartime rhetoric designed to mobilize men to fight, but in this case it also had the counterproductive effect of spreading terror in Republican territory. In the words of one Communist peasant, it was enough for someone to shout that the Moors were attacking for panic to spread. ${ }^{27}$

The primary objective of Republican discourse on the savage Moorish warrior was to attack the Nationalist leadership. Representations of the Moor served to condemn Nationalist generals for bringing moros to kill their own kin, drawing them to Spain with promises of women and loot. ${ }^{28}$ For example, the caption of the caricature of the savage Moor mentioned above read: 'los generales patriotas'. 'Los que se llaman patriotas ríen bestialmente cuando ven a las mujeres campesinas entregadas a la lujuria y a los bestiales instintos [...] de los moros mercenarios, ${ }^{2}{ }^{29}$ declared the Madrid newspaper El Sol. Another caricature by Luis Bagaría showed a simian general with a caption that read: 'Si yo pido ayuda a los moros es para que me enseñen a hacer Annuales', ${ }^{30}$ referring to the slaughter of Spaniards by Rifian rebels in the Annual Disaster. Nationalist generals were often represented as pathetic cowards hiding behind their Moorish mercenaries La figura del moro chulo y matacristianos se crece,' wrote Communist journalist Clemente Cimorra, 'y los generalotes, de rodillas [...] se agarran a las piernas del cabileño aguerrido para que los defienda de la falta de redaños de los de su casta'. ${ }^{31}$

Republican propaganda often contrasted the hyper-sexuality of the Moor with the lack of masculinity of the Nationalists ${ }^{32}$ and alluded to the fraternization of 'fascist' women with moros. A poem by José Bergamín ${ }^{33}$ provides an example of this discourse;

La media luna ya tiene

protección de las beatas.

${ }^{24}$ Clemente Cimorra, 'Mujeres de España: Botín de los moros', La Voz (20/08/1936): 1.

${ }^{25}$ Cimorra, 'Mujeres de España: Botín de los moros.'

${ }^{26}$ M. Martín, El Colonialismo Español en Marruecos (Paris: Ruedo Ibérico, 1973), 165, quoted in Martín Corrales, 'Entre el moro violador y el moro seductor', 229.

${ }^{27}$ Ronald Fraser, Blood of Spain: An Oral History of the Spanish Civil War (London: Pimlico, 1994), 162.

${ }^{28}$ Cimorra, 'Mujeres de España: Botín de los moros'.

29 'Qué cada acto, que cada fusil, responda siempre a un plan organizado, a una necesidad de la Guerra', El Sol (19/08/1936):4.

${ }^{30}$ Bagaría, 'El Militarista de tristes recuerdos', El Sol (27/08/36): 2.

${ }^{31}$ Clemente Cimorra, ‘Al moro su botín', La Voz (26/10/36): 4.

${ }^{32}$ Eloy Martín Corrales, La imagen del Magrebí en España: Una perspectiva histórica, siglos XIX-XX (Barcelona: Bellatierra, 2002), 160.

33 José Bergamín was a Spanish essayist, poet and playwright who maintained a close friendship with the Basque intellectual Miguel de Unamuno and is considered part of the Generation of 27. During the Civil War he presided over the Alianza de intellectuales anti-fascistas. 
¡Cómo curan sus heridas, cómo el moro les regala sangrientos ramos de flores

llenos de orejas cortadas! ${ }^{34}$

Again, this image of the savage Moor primarily serves the purpose of representing Nationalist women negatively. The insinuation was that these pious Catholic señoritas were actually lascivious and loose, seducing Moroccans because their own men could not satisfy them.

The Nationalist response to Republican representations of the Moor as a cruel savage was varied and somewhat contradictory. It is best exemplified in the notorious radio broadcasts of General Queipo de Llano, commander of the Nationalist forces in the south. On 23 July 1936, three days after the Army of Africa had defeated the final Republican resistance in Seville, he delivered the following speech:

Nuestros bravos legionarios y regulares han enseñado a los cobardes rojos lo que significa ser hombre. E incidentemente también a sus mujeres. Después de todo, a estas mujeres comunistas y anarquistas les ha hecho bien adoptar la doctrina de amor libre. Ahora conocerán por lo menos a hombres verdaderos, y no esos milicianos maricas. Por más que pateen y luchen no se salvarán. ${ }^{35}$

This contrasts with his "Christmas" speech in December 1936 in which he denied the mass murders of Badajoz, calling them the work of 'las turbas marxistas' 36 Queipo's broadcasts in July 1936 were an isolated case; the Nationalists did not usually brag about the atrocities of the Regulares. However, they demonstrate that Nationalists as well as Republicans integrated Orientalist fantasies about the savagery and hypersexuality of the Moor into their discourse, using them to de-masculinize their enemy and defame their women.

Queipo de Llano capitalized on the image of the savage Moorish warrior as a weapon of psychological warfare. Although the Nationalist rebels were well armed, in the early stages of the war they were few in number, so in a place like Seville, the large working class population needed to be 'terrified into acquiescence. ${ }^{37}$ Radio broadcasts, which reached the farthest corners of Spain, were highly effective in spreading this terror. The most dramatic representations of the savage Moor appeared between July and October 1936. Once the Nationalist army was reformed in October, the Regulares were incorporated into larger brigades with Spanish volunteers so there were no longer military units composed solely of Moroccans. ${ }^{38}$ As a result, the Republicans no longer experienced the psychological impact of being attacked by an army of Moors.

It is difficult to distinguish between fact and fiction in propaganda, and in any case that is not the purpose of this article. However, there is no doubt that Moroccan

\footnotetext{
${ }^{34}$ José Bergamín, 'El Mulo Mola', Poesía de la Guerra Civil Española, ed. César de Vicente Hernando (Madrid: Akal Ediciones, 1994), 261.

${ }^{35}$ I. Gibson, Queipo de Llano: Sevilla, verano de 1936 (con las charlas radiofónicas completas), quoted in Martín Corrales, 'Entre el moro violador y el moro seductor,' 221-2.

${ }^{36}$ La charla radiada anoche por el General Queipo de Llano', ABC Sevilla (26/12/1936):7

${ }^{37}$ Thomas, The Spanish Civil War, 219.

${ }^{38}$ Madariaga, Los Moros que trajo Franco, 272.
} 
soldiers did commit atrocities. Most of the Moroccans arriving in Spain were Berber tribesmen whose battle experience consisted of brutal guerrilla warfare against enemy tribes or against the Spanish army in the Rif campaigns. For these soldiers, mutilating the enemy and razing and pillaging after conquering their territory was common culture. ${ }^{39}$ Such actions were often ignored or sanctioned by their officers because looting was a cheap way of rewarding colonial troops, and because attrition against the civilian population was viewed by the Nationalists as a means of deterring further resistance. ${ }^{40}$ It should be noted, however, that in the colonial campaigns as well as in the civil war, Spanish soldiers were responsible for similar types of atrocities as Moroccans. ${ }^{41}$ For example, in 1922 the philanthropic Duchess of Victoria received a tribute from the Legion of a basket of flowers containing two severed heads of Moroccans. ${ }^{42}$ Bergamín's poem describing Spanish ladies receiving bloody bouquets of flowers was based on a real event, but it was Spanish rather than Moroccan soldiers who presented the bloody bouquet.

Nationalist discourse generally represented the fierceness of the Regulares as heroic rather than savage, portraying them as noble and courageous warriors. They were described as 'amantes de la Guerra', ${ }^{43}$ endowed with 'el espíritu de cruzada', ${ }^{44}$ 'nacidos con un rifle en la mano'. ${ }^{45}$ In this case, the Moorish warrior was not represented as the Other but as a martial ideal to aspire to. In Andalusia, through fierce fighting Nationalist militias known as soldaditos de Cádiz earned the right to call themselves Regulares de Cadiz. ${ }^{46}$ Here Orientalism helped to define the European not by setting him apart from the Oriental, as Edward Said famously argued, but rather by identifying with him.

All of the key figures of the Nationalist insurrection were defined by their experience of Morocco. Francisco Franco famously declared, 'sin África yo apenas puedo explicarme a mí mismo, ni me explico cumplidamente a mis compañeros de armas' ${ }^{47}$ In Nationalist discourse, Africa was portrayed as the birthplace of the new Spain. Tomás García Figueras, military officer, Arabist scholar and colonial administrator in Morocco between 1936 and 1956, presented this representation colourfully in his history of Spain and Morocco,

Barranco del Lobo, Anual y Monte Arruit no eran más que el precio doloroso de una obra fecunda de maternidad [....] Por obra de esa España auténtica, que representaba el Ejército, nacía en Marruecos, como término de un largo proceso histórico, un nuevo hijo espiritual de España. ${ }^{48}$

\footnotetext{
${ }^{39}$ Balfour, Deadly Embrace, 286.

${ }^{40}$ Balfour, Deadly Embrace, 286.

${ }^{41}$ Balfour, Deadly Embrace, 209.

${ }^{42}$ Paul Preston, Caudillo de España, trans. Teresa Camprodón y Diana Falcón (Barcelona: Circulo de Lectores D1, 1994), 49.

43 Ángel Doménech Lafuente, Un Oficial entre Moros (Larache: Artes gráficas Boscá, 1948), 21.

${ }^{44}$ García Figueras, Marruecos, 283.

45 Alejandro Manzanares, 'Los Moros Leales', Noticiero de Soria (18/01/1937): 1.

${ }^{46}$ Balfour, Deadly Embrace, 290.

${ }^{47}$ Manuel Aznar, Palabras del Caudillo: 19 abril 1937- 31 diciembre 1938 (Barcelona, 1939) quoted in Preston, Caudillo de España, 314.

${ }^{48}$ García Figueras, Marruecos, 283.
} 
García Figueras' statement that the military embodied the true Spain would become a pillar of Nationalist discourse. Since the early nineteenth century the army had regarded itself as the creator of the modern state and the rightful guardian of Spanish civilization. However, after society blamed the defeat of Spain in the Spanish-American war of 1898 on the military, a sense of betrayal in military circles fuelled the development of the radically anti-democratic and militaristic culture of the Africanistas. They as well as the other parties within the Nationalist camp saw themselves as redeemers of Castilian civilization and believed that redemption would be achieved through the civil war. The role of colonial Morocco in this narrative was fundamental, to the extent that $17 \mathrm{July}$, the anniversary of the military uprising, was declared 'el día de África'. On this date, Nationalist newspapers celebrated 'el pueblo marroquí, but Morocco itself was only represented for the sake of representing the glory of the Spanish military. An article published in 1938 in the ironically titled newspaper La Prensa: diario Republicano, described Morocco as the 'fecundo vivero' of the greatest traditions of the army, where the 'virtudes naturales' of the Spanish soldier were cultivated and the main figures of the present crusade were forged. ${ }^{49}$

Nationalist representations of Morocco and of the character of the Moorish warrior acted as a mirror, reflecting and reaffirming the Nationalist vision of themselves. The Foreign Legion provides a key example of how Africanista military culture re-assimilated Orientalist projections of Moroccan culture into their own masculine identity. ${ }^{50}$ Created by Lieutenant Coronel José Millan Astray in 1920 to fight in the Moroccan colonial campaigns, the Legion developed a hyper-masculine cult of virility and violence shaped by its interaction with Berber warriors. Millan Astray, who wore his numerous war mutilations 'like proud trophies of masculinity, ${ }^{51}$ described the 'espíritu del legionario, de ciega y feroz acometividad [...] Espíritu guerrero que busca embestir con ímpetu, acortar la distancia, clavar la bayoneta' 52

The Legion assimilated the theatrical war rituals of the Berbers, particularly their customs of mutilation, decapitation, and castration, gaining a fearful reputation for their brutality. ${ }^{53}$ They romantically represented themselves as a spiritual brotherhood, encouraging martyrdom for the cause of a military religion whose prayers were "valor, compañerismo ante el fuego [...] Disciplina, combate, muerte, y amor a la bandera'. ${ }^{54}$ Millan Astray represented death as the ultimate act of fulfilment of masculinity. Military historian Gabriel Cardona argues that this 'mitificación del sentido de la muerte' shaped the outlook of all the rebellious generals in 1936 as well as the values of the military dictatorship established by Franco after the Nationalist victory in $1939 .{ }^{55}$

The perceived virility, religious fanaticism and ferocity of Berber warriors also resonated with other parties in the Nationalist camp. Falangism glorified violence as a means for purifying society, as party founder José Antonio Primo de Rivera declared

${ }^{49 ، E l ~ h o m e n a j e ~ d e ~ E s p a n ̃ a ~ a l ~ p u e b l o ~ A f r i c a n o ’, ~ L a ~ P r e n s a: ~ d i a r i o ~ R e p u b l i c a n o ~(17 / 07 / 1938): ~}$

1.

${ }^{50}$ Susan Martín-Márquez, 'Performing Masculinity in the Moroccan Theatre: Virility, Sexuality, and Spanish Military Culture from the African War to the Civil War', European Review of History Vol. 11, No. 2 (2004): 237. Doi: 10.1080/1350748042000240569.

${ }^{51}$ Balfour, Deadly Embrace, 174.

52 José Millan Astray, La Legion (Leganés: Subinspección de la Legión, 1922), 30.

${ }^{53}$ Martín-Márquez, 'Performing Masculinity in the Moroccan Theatre', 237.

${ }^{54}$ Millan Astray, La Legion, 29.

${ }^{55}$ Gabriel Cardona, El Gigante Descalzo: El ejército de Franco (Madrid: Aguilar, 2003), 132. 
at a right-wing convention in Madrid in 1933: 'si la libertad del ser humano sólo se puede lograr mediante la violencia, no dudemos en emplearla'. ${ }^{56}$ The Falangist martial ideal was the 'sacerdote guerrero', the embodiment of the noble, austere, fervently Catholic Castilian knight of the sixteenth century. Representations of the Moroccan soldiers in Nationalist discourse echoed this ideal. The Moroccan soldier was described as having 'virtudes inquebrantables [...] honor, jerarquía, y fe'. ${ }^{57}$ The representation of religious fanaticism resonated with the fiercely Catholic Carlistas, but the Nationalists tread carefully around the fact that the Moroccan was a 'fanatical' Muslim, the traditional enemy of Christianity.

The Nationalists were united by their exaltation of the abstract values associated with war and soldierhood: glory, honour, sacrifice, and above all loyalty to the Fatherland. The title given to Franco as their leader was Caudillo. In Nationalist ideology, the warrior was the epitome of masculinity and of patriotism, and in the self-construction of their martial identity the Nationalists were inspired by their representation of the Moroccan warrior.

\section{El moro hermano}

Edward Said described the Orient as 'culturally, spiritually, and intellectually outside of Europe and European civilization.' 58 While this is true of British and French Orientalism, it is not true of Spain with its cultural and historic links to Islamic civilization. Although Spanish Orientalism also justified European superiority, it was unique in its identification with the Other. Maurophobia and maurophilia have long been a feature of Spanish culture; ${ }^{59}$ alongside the representation of the Moor as the enemy Other there has always been an element of fascination with the Moors and admiration for the great civilization of Al-Andalus. The maurophilial image of a cultural, religious, and military brotherhood between Spain and Morocco was a central part of Nationalist discourse. Conversely yet similarly, the notion of a 'class' brotherhood between the Spanish and Moroccan people was a significant theme in Republican discourse.

The image of the Moroccan as a younger, weaker brother of Spain was developed in colonialist discourse at the turn of the twentieth century to justify Spanish influence in Morocco. Colonial administrators described Spaniards and Moroccans as originating from the same race, 'unidos por vínculos históricos y geográficos, laborando juntos para lograr el progreso de la civilización'. ${ }^{60}$ This discourse was carried over into the civil war. Once the representation of the Nationalist uprising as a Catholic crusade began to take shape a few weeks into the war, the cross and the crescent were portrayed as brothers, fighting side by side in the name of religion against the godless judeo-masonic-marxist alliance. Tomás García Figueras's narrative of the civil war provides a prime example of this discourse:

${ }^{56}$ Speech by José Antonio Primo de Rivera at the Teatro de la Comedia in Madrid on October 29th, 1933, quoted in Joan María Thomàs, Lo que fue la falange: La Falange y los falangistas de José Antonio, Hedilla, y la unificación, Franco y el fin de la Falange Española de la JONS (Barcelona: Plaza \& Janés, 1999), 31.

${ }^{57}$ Manuel Sanchez del Arco, 'Ayer Mismo', ABC Sevilla (21/10/1938): 5

${ }^{58}$ Said, Orientalism, 70.

${ }^{59}$ Goytisolo, Crónicas Sarracenas, 21.

${ }^{60}$ Speech by General Burgete, the Spanish High Commissioner in Morocco at a ceremony in Tetuán, 1922, quoted in Jensen, 'The Peculiarities of 'Spanish Morocco', 101. 
Al otro lado del estrecho [...] había un hermano musulmán que se sentía, en su independencia y con un sentido preciso de su nacionalidad y de su religión, unido a nuestra misma patria por lazos de amor [...] El indígena se uniría a ella con toda la devoción y todo el cariño de un hermano, pidiendo para él el honor de compartir con los españoles la lucha a muerte contra los enemigos de la civilización y contra los hombres sin Dios que amenazaban hundir una cultura de Occidente de la que la hispanidad y el arabismo habían sido los mejores artífices. ${ }^{61}$

García Figueras provides an overview of the history of Spain and North Africa, beginning with $\mathrm{Al}$ Andalus, which he paints as a glorious period of 'convivencia' between Arab, Berber, and Iberian Muslims and Christians. He emphasizes the similarities between Christianity and Islam; gong as far as to quote Catholic Arabist Miguel Asís Palacios in saying that Islam was 'practicamente una secta del cristianismo'. ${ }^{62}$ His narrative culminates in the Spanish colonization of Morocco, the beginning of Spain's 'obra fraternal' of rescuing the once- great North African civilization from decay. ${ }^{63}$

The representation of the Moroccan as a weaker brother affirmed the imperial destiny that the Nationalists imagined for Spain. Franco and the falangistas were obsessed with the grandeur of 16th-century Spanish empire and envisioned Morocco as the place where this empire would be reborn. The image of the Moorish brother was also used to nourish the cult to Franco. Nationalist poet and politician Pedro Escalante y Huidobro described Franco as 'El Caudillo cuya espada ganó de Africa arisca el ardiente corazón', ${ }^{64}$ who was worshipped by the Moroccan recruits with religious devotion. 'Ante los ojos atónitos y fanatizados del rifeño montaraz', remarked the regional newspaper Noticiero de Soria in January 1937, 'Franco ha adquirido la categoría de ser sagrado [... ] El jefe recto, austero, justo, benévolo y ejemplar [...] que le llena de esperanza'. ${ }^{65}$ Africanist officer Ángel Doménech Lafuente draws on the same image to describe the Berber soldier: 'El Berber es un soldado que ama la Guerra [...] lo que busca es un jefe que respetar. Este jefe lo ha encontrado en la figura de Franco. ${ }^{, 66}$ On the Nationalist Orientalist stage, Moroccan soldiers played the role of exalting el Caudillo.

The notion of brotherhood clearly sought to justify the use of Muslim troops in the Nationalist crusade. Reshaping discourse on the Moorish Other was necessary because the recruitment of Moroccans was fundamental to the Nationalist cause, ${ }^{67}$ but underneath this affectionate discourse lay the prejudices that characterized all European colonial relationships. The Nationalists proclaimed reverence towards Islam when general opinion among the military in Morocco was that Islam was the 1941), 229.

${ }^{61}$ Tomás García Figueras, Marruecos: la acción de España en el norte de África (Madrid: Fe,

${ }^{62}$ García Figueras, Marruecos, 32.

${ }^{63}$ García Figueras, Marruecos, 7.

64 'Pedro de Escalante y Huidobro, 'Romance de Jamido '(1937) in En Campaña- Poesias (Santander: Aldus, 1940), 46.

${ }^{65}$ Alejandro Manzanares, 'Los moros leales', Noticiero de Soria (18/01/1937): 1.

${ }^{66}$ Lafuente, Un Oficial entre Moros, 24.

${ }^{67}$ Balfour, Deadly Embrace, 280. 
cause of the backwardness of the Moors. ${ }^{68}$ They highlighted the shared racial characteristics between Moroccans and Spaniards, but treated their colonial subjects with the same attitude of racial superiority as did British and French colonists. In his memoirs Franco fondly remembers an old legionnaire in Morocco who, when told to stop shooting at Moroccan women, responded, ‘ipero si son fábricas de moritos' ${ }^{69}$ Mohammad Ben Sidi Lahsen, the creator of the military brotherhoods funded by the tribes to oppose Spanish expansion in Morocco, said of the Spanish, 'desprecian nuestra cultura y odian nuestra religión' ${ }^{70}$

Moroccans did not 'adore' Franco and arrive in Spain joyfully and impatiently to claim their place of honour in the civilizing crusade as García Figueras claimed. ${ }^{71}$ The Nationalist army succeeded in recruiting large numbers of men from the Spanish and French areas of Morocco mainly because the army compensation (food rations for soldiers' families as well as a regular salary) offered an escape from destitute poverty. ${ }^{72}$ However, in some areas Spanish authorities resorted to coercive methods because recruitment was met with fierce resistance. Peasants in Yeballa sold their livestock and sought refuge in Tangiers to avoid recruitment. ${ }^{73}$ Other tribes in the Central Rif organized armed resistance. Tribal leaders who opposed recruitment were threatened and in some cases even executed. ${ }^{74}$ Spanish authorities used their control of food supplies and grants to reward families that had contributed soldiers and to punish those that had refused. ${ }^{75}$ In December 1936 a French newspaper reported that 800 local workers who had been hired by the military for a public works project had been given soldiers uniforms and told they were to receive military training so they could join the army. ${ }^{76}$ These facts indicate that neither the Spanish nor the Moroccans were convinced by this discourse of brotherhood.

The Republican press seized on the contradictions and insincerities of the Nationalist discourse of brotherhood. The image of moros y cristianos marching arm and arm appeared in Republican propaganda, especially in the anarchist press, as an attack on the lack of ideals and principles of their opponents. In August 1936, CNT, the Madrid publication of the Spanish confederation of anarcho-syndicalist labor unions, commented; 'los mismos generales que declararon la guerra contra el moro infiel le traen ahora a España',77 They reported that Moors commonly looted churches, citing as proof the fact that Moroccan prisoners captured by the Republicans had religious relics among their possessions.

Ríete de los que te hablan de los rifeños como gente ansiosa de verter sangre de cristianos [...] La cuestión religiosa no existe para aquellos yeballa. Son gente [...] que piensa con la barriga, como nuestros prelados

${ }^{68}$ Josep Lluís Mateo Dieste, La «hermandad» hispano-marroquí: Política y religión bajo el Protectorado español en Marruecos (1912-1956) (Barcelona, Ediciones Bellaterra, Colección Alborán, 2003), 21.

${ }^{69}$ Franco, 'Marruecos: Diario de una bandera', 21.

${ }^{70}$ Balfour, Deadly Embrace, 41.

${ }^{71}$ García Figueras, Marruecos, 229.

${ }^{72}$ Madariaga, Los moros que trajo Franco, 274.

${ }^{73}$ Madariaga, Los moros que trajo Franco, 177.

${ }^{74}$ Madariaga, Los moros que trajo Franco, 174.

${ }^{75}$ Boletín Oficial de la Zona del protectorado Español en Marruecos,(1937): 21, quoted in Balfour, Deadly Embrace, 276.

${ }^{76}$ La Dépêche Marocaine, quoted in Bullein du Comité de L;Afrique Française (Jan. 1937): 41-42, quoted in Balfour, Deadly Embrace, 276.

${ }^{77}$ CNT (21/08/1936): 1. 
cristianísimos. Es todo rapiña- Desde Franco, Mola [...] el Obispo de Segovia, y sus compañeros hasta el último Mohamed africano. ${ }^{78}$

It is not surprising that the anarchists, who fixated on the materialism and hypocrisy of the Catholic Church and were at times fanatically anti-clerical, should choose to attack the Nationalist leadership through this 'religious question'.

Contradictions and inconsistencies are also found in Republican discourse. While Republican propaganda represented the Moor as a cruel savage and mocked the Nationalist alliance with the infidel, they also adopted a parallel discourse of brotherhood, representing the Moroccans as fellow victims of fascist oppression and brothers in the international working class struggle. 'El campesino marroquí, como el campesino español, no desea más que cultivar su pequeño pedazo de tierra', declared El Sol in December 1937,

Ha venido a España engañado por un falso espejismo. [...] Los mismos que $[\ldots]$ lo persiguieron durante siglos, los mismos que lo explotaron y esclavizaron, son los que lo han traído a luchar ahora contra quienes podrían darle, y le dan, al fin, la libertad ${ }^{79}$

Republican sources claimed that the Moors had been lured to Spain with false promises of land and women, ${ }^{80}$ that they were not paid or were given worthless German marks from the Weimar era, ${ }^{81}$ and that Catholic rites were imposed on them. ${ }^{82}$ There was certainly some truth to these claims. As Balfour and Madariaga have noted, providing evidence from soldiers' testimonies and reports by the colonial administration, Moroccans in the Nationalist army were often subject to abuses and injustices. $^{83}$

The Republican press also reported on the aforementioned resistance movements in Morocco. In August 1936, the same month that the press was filled with stories of Moorish atrocities in Andalusia and Extremadura, CNT and El Sol reported that there was social unrest in Morocco, where many Moroccans were profoundly opposed to fighting against the Republic. ${ }^{84}$ In October they reported that in many villages women were gathering to protest against recruitment, ${ }^{85}$ and that Spanish authorities responded by threatening and beating both men and women. ${ }^{86}$ 'En Marruecos', El Sol declared in February 1937, 'el Moro trabajador y digno sufre las mismas violencias que nuestros proletarios' ${ }^{87}$

The Republican representation of the Moorish brother was, at least in part, designed to encourage desertion by discrediting and demonizing the Nationalists.

78 'Los Moros saquean las iglesias,' CNT, (19/08/1936), 2.

${ }^{79}$ María Luisa Carnelli, 'Los Moros del Fascismo', El Sol (14/12/1937): 1.

${ }^{80}$ Carnelli, 'Los Moros del Fascismo'.

${ }^{81}$ 'España se bate no solo por su porvenir de pueblo libre, sino por lo que podemos llamar fuente mundial de la libertad', El Sol (02/12/1936): 1.

82 'Los Moros siguen abandonando a Franco', El Sol (31/12/1936): 1.

${ }^{83}$ Balfour, Deadly Embrace, 279.

84 'Los manejos de Franco', CNT (18/08/1936): 1, 'En Africa hay inquietud', El Sol (16/08/1936): 4.

85 'Sidi Azer Kan subleva a Beni Urriaguel contra el Faccioso Franco', El Sol (01/10/1936): 1.

86 'Se detiene al caíd de un poblado por el rumor que simpatizaba con el gobierno de la República', El Sol (11/10/1936): 1.

87 'En Marruecos, el Moro trabajador y digno sufre las mismas violencias que nuestros proletarios', El Sol (13/02/1937): 1. 
There were explicit efforts to incite Regulares to join the Republican army, including the distribution of pamphlets and speeches in Arabic delivered over loudspeakers. These strategies were not particularly effective, as most Moroccan recruits were illiterate or spoke only the Berber language tafiriq. ${ }^{88}$ The press also promised that the Republic would do everything in its power to strive for the freedom of Morocco. ${ }^{89} \mathrm{In}$ reality, the Republican government made no effort to establish an alliance with the Moroccan nationalists. Overwhelmed by the war and afraid of alienating potential support from France, Republicans failed to seize the opportunity to undermine the Nationalist rebels by offering autonomy or independence to the Spanish protectorate. ${ }^{90}$ On the other hand, the Nationalists made promises of independence that they never intended to keep. Ultimately, Spanish Republicans did not identify with the Moroccan 'workers' any more than Nationalists identified with their Muslim 'brothers'.

In Orientalist discourse, The Oriental is a character created by Europeans who speaks 'through and by virtue of the European imagination. ${ }^{91}$ He has no voice of his own; rather he is contained and represented by Europeans who use him to impose their will. 'Interviews' and 'declarations' by moros in Republican and Nationalist newspapers demonstrate this principle. They are ventriloquist acts, so to speak, where Spaniards used the character of el moro as a mouthpiece for their discourse. Both Republican and Nationalist sources adhered to the racial stereotype of the Moor as a simpleton, quoting Moroccans as speaking 'en moro', in other words, in broken Spanish and in third person. For example, an article in El Sol quoted the last words of a Moroccan who died in a hospital in the following manner; 'Moro en España no estar bien. Siente mucho frío y faltarle sus cosas. No tiene guitarra. Está triste'. ${ }^{92}$ The following two examples illustrate how both camps invented characters to represent their Orientalist stereotypes.

In December 1936, Imperio, a Falangist newspaper in the northwestern region of Zamora, published the 'declaration' of a wounded moro named Larbi Ben Mohamed at a hospital in Zamora that could have been written by Garcia Figueras himself,

No hay nada que mirar en este mundo, solamente Dios y España porque ella fue la única que llevó la primera luz de civilización al pueblo musulmán [...] ayudando al pobre y al rico, respetando las leyes árabes y la religión, por ese bienhechor de obra de caridad y de hermandad de nuestra civilizadora y protectora querida hermana España, alzamos la vista al cielo con las armas en la mano y gritamos [... ¡ iViva España! ${ }^{93}$

${ }^{94}$ Ben Mohamed recites perfectly the lines that have been written for him to perform the role of submissive Muslim brother. Similarly, in August 1936 El Sol published the 'testimony' of a Moroccan prisoner describing his experience in the Nationalist

\footnotetext{
${ }^{88}$ Martín Corrales, La imagen del Magrebí en España, 166.

89 'España se bate no solo por su porvenir de pueblo libre, sino por lo que podemos llamar fuente mundial de la libertad', El Sol (02/12/1936): 1.

${ }^{90}$ Balfour, Deadly Embrace, 274.

${ }^{91}$ Said, Orientalism, 56.

92 'Un moro siente frío y está triste sin su guitarra', El Sol (27/10/1936): 1.

93 'Palabras de un bravo Moro, hospitalizado en Zamora', Imperio: Diario de Zamora de Falange Española de las J.O.N.S, Year I No.38 (12/12/1936): 7.

94'Palabras de un bravo moro', 7.
} 
army. ${ }^{95}$ He claimed that they were told they were coming to Spain to crush an uprising against the Republic, that the campaign would be short and that they would be given land in Spain. None of these promises were kept, instead they were underpaid, their religion was not respected, and they were hated everywhere they went. 'Si en Marruecos se supiera la verdad, no habría ningún moro que quisiera pasar a España para guerrear'. ${ }^{96}$ In this case, the Moor plays the aforementioned Republican character of pitiful victim of fascism.

Unfortunately, there are few recorded testimonies of Moroccans that fought in the Spanish Civil War. ${ }^{97}$ Balfour included interviews with veterans in his work Deadly Embrace, as did filmmaker Driss Deiback in his documentary on Moroccan participation in the war. ${ }^{98}$ One of the soldiers interviewed by Deiback described his experience with the Nationalists as follows; 'nos metieron como a gatos en un saco, nos soltaron en España y nos dijeron: ¡a disparar o a morir'! ${ }^{99}$ Another veteran interviewed by Balfour claimed that Moroccan troops were constantly overexposed to enemy fire and that when they were sent into action, their officers would invariably follow them in the rearguard. ${ }^{100}$ These interviews reveal a sense of injustice in the memory of the Nationalists' treatment of the Regulares. On the other hand, some veterans interviewed by Balfour remember their officers with sympathy. ${ }^{101}$ In any case, the small number of testimonies recorded by Balfour and Deiback cannot be considered representative of the experience of the Regulares in Spain. Most of these narratives have now passed into history in silence.

This article deals with representation rather than historical memory. However, the lack of texts on the experience of the Regulares is worth noting because it demonstrates the predominance of Orientalist representations of Moroccans in the history of the Civil War. In this case the Moroccan soldier truly has no historical voice other than the voice given to him by Europeans.

\section{El moro invasor}

Benedict Anderson famously argued that the nation is a community imagined as both inherently limited and sovereign. ${ }^{102}$ It is defined by drawing links with the past to create a historical myth that justifies the existence of the nation in the present. It is also constructed in opposition to the Other that lies outside of its imagined boundaries.

There were many conflicting definitions of Spain constructed during the war that cannot simply be categorized as Nationalist or Republican. Franco's leadership unified the groups within the Nationalist camp, but Republicans were extremely fragmented in their vision of Spain, united only by their opposition to fascism. The nuances of identities in the Spanish Civil War cannot be addressed at length in this article, but a common theme that emerges in the struggle to define the nation is the

\footnotetext{
95 'Lo que cuenta un moro prisionero', El Sol (27/08/1936): 1

96 'Lo que cuenta un moro prisionero'.

${ }^{97}$ Sebastian Balfour, email message to author, June $8^{\text {th }}, 2012$.

${ }^{98}$ Driss Deiback, Los Perdedores (Barcelona: ZIP Films, 2006).

${ }^{99}$ Interview with Mimou Mohammedi, Deiback, Los Perdedores.

${ }^{100}$ Interview with Mohammed Ayache Zeruali, quoted in Balfour, Deadly Embrace, 307.

${ }^{101}$ Balfour, Deadly Embrace, 307.

102 Benedict Anderson, Imagined communities: reflections on the origin and spread of nationalism (London: Verse, 1991), 5.
} 
significance of the image of the Moorish Other. Although they were fighting against fellow Spaniards, Republicans and Nationalists portrayed each other as foreign invaders attacking from outside the boundaries of the true nation, a representation that has been examined in detail by Xosé Nuñez Xeixas. ${ }^{103}$ Republicans referred to their enemy as 'el fascismo internacional' or 'la alianza marroquí-germano-italiana', while Nationalists referred to Republicans as la 'conspiración judeo-masónica' or 'la barbarie asiática'.

These representations were based on a reality of foreign intervention on both sides: Mussolini and Hitler provided troops and weapons to Franco, and Russia and the International Brigades, a military force composed of volunteers from various countries, aided the Republic. In the Spanish collective imagination, the quintessential foreign enemy was el moro invasor, therefore both sides employed this representation invoking the same symbols and historical myths; the battle of Covadonga, the Reconquest of Granada, and the figures of Pelayo, El Cid, and Santiago matamoros. Likewise, both sides took on a heroic role against the invader in their national narrative.

Republican propaganda used the image of the Moorish invader to exclude the Nationalists from their imagined community and represent themselves as defenders of that community. Because the rebels had brought the Moors, the traditional enemy of Spain, back to Spain to spill Spanish blood, they had lost the right to call themselves Spanish. ${ }^{104}$ Republicans portrayed themselves as protecting what was sacred; the fatherland, freedom, and civilization, now threatened, as El Sol declared in August 1936, by 'la barbarie de los generales insurrectos, que emplean tropas de color, con el intento de aniquilar a los hermanos de raza, a los compatriotas'. ${ }^{105}$ This form of discourse often had a strongly racist tone, excluding moros racially as well as culturally. In a speech in September 1936, future anarchist minister Federica Montseny described Franco as follows:

Ese enemigo sin dignidad ni conciencia, desprovisto del sentimiento español, porque, si lo tuviera, si fuera Patriota, no hubiera arrojado en España la legión Extranjera y los Marroquíes, imponiendo la civilización del fascismo [...] una civilización árabe, de gente que hemos colonizado y que realmente ahora nos colonizan. ${ }^{106}$

The Republican vision of Spain also excluded the Nationalists, whose betrayal placed them outside of the nation. A poem published in El Mono Azul in October 1936 exemplifies this representation:

Huirás como una pantera

Por los desiertos de África

bajo el aliento indomable

de los soldados de España.

Huirás con los legionarios

y rifeños de tu casta

que eres de ellos y no nuestro

${ }^{103}$ See Xosé M. Nuñez Xeixas, Fuera el Invasor: Nacionalismos y movilización bélica durante la Guerra Civil Española (1936-1939) (Madrid: Marcial Pons Historia, 2006).

104 'Los sediciosos han perdido el derecho de llamarse españoles', El Sol (23/08/1936): 1.

105 'Los sediciosos han perdido el derecho de llamarse españoles'.

${ }^{106}$ Federica Montseny, 'Discurso', Solidaridad Obrera (02/07/1936): 1. 
como traidor a tu patria ${ }^{107}$

As we have seen consistently in Republican propaganda, here the representation of the Moor served the purpose of delegitimizing the Nationalist leadership, who were portrayed as cruel, cowardly and effeminate, lacking any ideals or sense of conscience. Conversely, it validated the Republican image of themselves as 'true' Spaniards. An article published in 1938 in the Catalan daily newspaper $\mathrm{La}$ Vanguardia entitled 'Siempre los mismos: El español de ayer, de hoy y de mañana', detailed the historical role of the Spaniard:

Intratable y soberbio siempre, echado hasta el mar por los moros y reconquistando palmo a palmo su patria por obra de una cruzada de 8 siglos [...] endurecido por la duración y la monotonía de la lucha [...] Uno y el mismo en los tiempos del Cid, en los de Felipe II y Carlos II, en la guerra de 1700, en la de 1808 y en el caos de despotismo [...] que hoy padece la nación. ${ }^{108}$

In this case, Republican discourse invoked the traditional myth of the Reconquista, as well as other historical myths of resistance, to construct an imagined community of Spaniards who had possessed these heroic qualities throughout history. This rhetoric was probably designed to inspire a morale boost by reminding Spanish Republicans of the legacy that united them. Because Republican identity was so fragmented, from the early stages of the war the search for unity was an important propaganda objective. Thus Republicans defined themselves in opposition to the Moorish Invader, who was the same enemy in 1936 as in the Reconquista, the first glorious war that had united Spain. A Madrid speech by Julio Just, the Republican minister of Public Works in 1936, exemplifies this rhetoric:

Los facciosos traen hasta los muros de Granada y hasta la brava Asturias los moros que fueron arrojados por Pelayo y por los Reyes Isabel y Fernando [...] en sus frentes no hay españoles, sino extranjeros, moros y la hez de la sociedad internacional. Con nosotros están los proletarios de toda España, unidos en un mismo afán: Derrotar al fascismo. ${ }^{109}$

These sources illustrate the ways in which symbols of resistance against the Moorish invader were invoked to unify and legitimize the present struggle of the Republicans. It should be noted that this image was not only applied to Moroccans. Republican newspapers sometimes referred to the Germans as moros rubios. ${ }^{110}$ The traditional enemy in the Spanish imagination is the Moor, and the Republicans drew on this image to define themselves in opposition to their enemy.

Nationalist discourse also invoked the traditional image of the Moorish invader, but in their case the representation was inverted. Drawing on the same historical symbols, the Nationalists portrayed the Republicans as the new Moors. 'Nuestro generalísimo, como antaño el Rey Pelayo, derrotará en Covadonga no un

107 'Franco, el pirata', El Mono Azul (01/10/1936), 5.

108 'Siempre los mismos: El español de ayer, de hoy, y de mañana, La Vanguardia, (17/06/1938): 1 .

109 Julio Just, 'Por izquierda Republicana', El Sol (15/10/1936): 3.

${ }^{110}$ For example: 'La mala situación', ABC Madrid (12/12/1936): 7. 
ejército moro sino la barbarie bolchevique, convertida en manada asesina', ${ }^{111}$ proclaimed La Prensa in September 1937. The Nationalists imagined themselves as saviours of civilization, fighting to rescue it from barbarism in 1936 just as their heroic forefathers had done throughout history. La misión sagrada de España siempre ha sido la salvación del mundo civilizado de todo tipo de peligros: Expulsando a los moros, deteniendo a los turcos, bautizando a los indios', declared the monarchist poet Jose María Pemán:

Ahora nuevos turcos, la cruel barbarie asiática, vuelven a amenazar a Europa. Pero la España de hoy, como la de ayer, se enfrenta a ellos, salvando así la civilización. Porque esta es una guerra santa. Una cruzada civilizadora. ${ }^{112}$

It is worth noting that Pemán used the term turco instead of moro. Moro was usually the term applied to all Muslims, but since the Nationalists used it in their discourse on the Moroccan 'brother' they could not use it also to describe their enemies. There are various interesting iconographic examples of this inverted representation. For instance, during the war the Bishop of Pamplona ordered the building of a statue dedicated to Santiago matamoros to replace an altarpiece in the church of his hometown in Andalusia that had been burned down by miners in July 1936. Instead of the customary image of the saint killing the Moor, the Bishop had the Moor replaced with an effigy of Lenin. ${ }^{113}$ When Coronel Ben Mizzian was promoted to general, the only Moroccan to reach this rank in the Spanish army, he was responsible for making the annual offering to the apostle Santiago. To avoid offending him, the Moors that the image of Santiago is butchering were discreetly covered with flowers and a sheet. ${ }^{114}$ Reportedly another official replaced him in the ceremony, but the irony of a moro presenting an offering to 'el matamoros' was not lost on observers.

As Nuñez Xeixas notes, for the Nationalists everything began for the sake of history and in the name of history. ${ }^{115}$ According to the first history textbooks published in the Nationalist zone in 1938, Spain had suffered three foreign invasions throughout its history: First by the Moors in 711, then by Napoleonic troops in 1808, and finally by the 'reds' in $1936 .{ }^{116}$ Thus, Nationalist Spain was defined by its version of history. Since the Reconquista, Spain had acted as the beacon of civilization, defending it when threatened and carrying it, with the cross and the sword, to the uncivilized world in the name of God and the Fatherland. This narrative would form the basis of Franco's National Catholicism. As in Republican propaganda, the image of the Moorish Other was employed to exclude Spaniards on the opposite side from the imagined boundaries of the nation. A chilling example of this discourse is found in the speech delivered by the Bishop of Badajoz on 14 August 1936, the day of the massacre:

${ }^{111}$ Hildebrando Padrón, 'Covadonga', La Prensa: Diario republicano, Year XXVII No. 10260 (28/09/1937): 2.

112 Fraser, Blood of Spain, 154.

113 Balfour, Deadly Embrace, 282.

${ }^{114}$ Madariaga, Los moros que trajo Franco, 276.

${ }^{115}$ Nuñez Xeixas, Fuera el Invasor, 228.

${ }^{116}$ Nuñez Xeixas, Fuera el Invasor, 228. 
Todas a una para exterminar a los enemigos de Dios, que son los enemigos de la patria [...] Unión, total sumisión al caudillo, para hacer una España como la de Isabel y Fernando. La cruz y la espada unidas darán días de gloria a nuestra patria que, una vez más, cumple la misión histórica de salvar al mundo de la barbarie. ${ }^{117}$

Nationalist discourse dehumanized Spanish Republicans, describing them as 'salvajes turbas rojas'118 or 'canallas marxistas'. ${ }^{119}$ Conversely, moros, who had traditionally been outside of the imagined boundaries of Spain, were now included in the Spanish community. This particular representation appears to evolve over the course of the war. In 1936 the Moroccans were hailed as noble warriors, especially in contrast to the Republican 'bárbaros'. Queipo de Llano described them in such terms:

Esos hombres de Marruecos son diez mil veces más caballeros que todos los que figuran en el Frente Popular y son mucho más dignos y tienen una sangre mucho más noble, que están dispuestos a derramar gota a gota siempre que sea posible para la salvación de España. ${ }^{120}$

Queipo described the Moroccan soldiers as worthy men, but did not go as far as to call them Spaniards. However, by 1938 Nationalist propaganda was praising the 'probado españolismo de los marroquíes'. ${ }^{121}$ The Falangist Count of Foxá described the Moroccans as bronze-skinned Spaniards;

Si mueres, Abdelazis

Sobre los surcos de España [...]

Los poetas de Castilla

Te dirán con lengua brava:

'También tienes tu lucero

Español de piel tostada' 122

This evolution of discourse can be explained by the forging of a strong Nationalist military identity through the experience of war that incorporated the Moroccan Regulares. 'La Guerra y la Muerte', in the words of Millan Astray, 'son el nacimiento de una hermandad militar, guerrera, heroica'. ${ }^{123}$ As previously noted, some Moroccans formed close bonds with their Spanish officers, and after fighting alongside Moroccans for two years (or much longer in the case of colonial officers), at least in their discourse the Nationalists were willing to consider the Regulares as fellow members of their community. Yet as Benedict Anderson has noted, the nation is always conceived as a deep, horizontal comradeship, regardless of the actual inequality and exploitation that may prevail. ${ }^{124}$ As in the case of the representation of the brotherhood of the cross and the crescent, the Republican press seized on the irony of this inclusion of the Moors in the Nationalist community, using it to discredit their

${ }^{117}$ Bahamonde, Memorias de un nacionalista, 63.

118 'Discurso de Queipo de Llano', ABC Sevilla, (03/12/1936): 7.

119 'Covadonga', Prensa Republicana, 2.

${ }^{120}$ Discurso de Queipo de Llano’, ABC Sevilla, (03/12/1936): 1.

121 'El homenaje de España a África', La Prensa: Diario republicano, Year XXVII, No. 10502 (17/07/1938): 2.

122 Agustín Foxá, 'Romancero de Abdelazis', ABC Sevilla (16/02/1938): 1.

123 Astray, La Legión, 32.

${ }^{124}$ Anderson, Imagined Communities, 7. 
opponents. ${ }^{125}$ As Clemente Cimorra remarked, 'tenían que ser los monopolizadores del amor patrio quienes pensaran hacer de los rifeños una especia de ciudadanos de primera clase en esa España abominable'. ${ }^{126}$

It has been argued that Franco transferred his colonial attitudes to Spain, treating Republican Spaniards the same way he treated Rifian rebels in Morocco, as children to be pacified with heavy-handed paternalism. ${ }^{127}$ It is true that the Nationalists employed many of the military tactics that were used in the Moroccan colonial wars, such as the strategy of bombarding and then sending in shock troops to 'cleanse' the area, or allowing razing and pillaging. ${ }^{128}$ Yet this is not surprising, as the only military experience that Spanish officers and their colonial troops possessed was in Morocco. Likewise, Balfour argues that the rhetoric used to describe the Rifian enemy in the colonial wars was applied to Republicans during the Civil War. However, Nationalist discourse drew mainly on the mythology of the Reconquista, portraying the enemy as the new Moorish Invader rather than the savage colonial rebel of the Rif campaigns. The medieval Moorish Other could be invoked less problematically than the Rifian rebel who was now fighting in the ranks of the Nationalist army.

Wartime discourse is ultimately pragmatic; it conceals, exaggerates, and distorts the truth to suit its purposes. In a civil war, it is designed to slice the country in half and persuade brother to fight against brother. Nationalist and Republican discourse redefined the boundaries of Spain and portrayed the opposing side as foreign invaders attacking from outside of the 'true' nation. As this article has shown, the image of the Moor played a central role in the definition of each of their visions of Spain and of the Other.

Over the course of the civil war, Nationalists and Republicans invented different characters to represent el moro, drawing from a deep well of historical symbols, cultural prejudices, and racial stereotypes. These representations served the purpose of building up or tearing down different visions of Spanish identity and drawing imagined boundaries to divide a nation that was embroiled in a bitter war.

In a speech to Moroccan soldiers in April 1937, Franco promised: 'Cuando florezcan los rosales de la victoria, nosotros os entregaremos sus mejores flores' ${ }^{129}$ In the victory parade in May 1939, the Regulares were the most decorated unit in the Nationalist army. ${ }^{130}$ It has been estimated that one in every five Moroccans that came to fight in Spain was killed, a casualty rate twice as high as the Spanish rate. ${ }^{131}$ To commemorate their heroic role in the war, Franco chose a select squadron of Moorish soldiers to act as his escort at public ceremonies. The image of the Guardia Mora, threatening and exotic in their capes and turbans, was a constant reminder to Spaniards of the importance of the Moor in the Nationalist crusade.

In reality, the heroism of the Moroccans was not remembered for long. When Morocco gained its independence in 1956, most units of Regulares became part of the

\footnotetext{
125 'El oro y el moro', El Sol (27/08/1936): 1.

126 'El oro y el moro'. Spain (2006)

${ }^{127}$ See Balfour, Deadly Embrace (2002), Preston, Franco (1994), and Beevor The Battle for

${ }^{128}$ Madariaga, Los moros que trajo Franco, 255.

${ }^{129}$ Madariaga, Los moros que trajo Franco, 344.

130 'Ben Mizzian, El general moro', Documental de la RTve, 6 July, 2012

http://www.rtve.es/alacarta/videos/el-documental/documental-2-ben-mizzian-general-moro/1457019/.

${ }^{131}$ Abdelhajid Benjellon, 'La participación de los mercenarios marroquíes en la Guerra Civil española, Revista internacional de sociología, ser.2, 46:4 (1988:Oct./Dec.): 527.
} 
Moroccan armed forces, so veterans in these units lost the right to receive pensions from the Spanish government. ${ }^{132}$ Pensions that were still granted were significantly reduced to an amount far inferior to the pensions of Spanish veterans. Although the orphans and widows of Moroccan veterans were entitled to pensions, many deaths were not reported, and as a result the families of these men did not receive a dime. According to a source from the Spanish embassy, until recently, in villages in the north of Morocco it was common to see widows of Spanish Civil War veterans begging on the streets. ${ }^{133}$ As Said argued, Orientalist discourse does not represent reality. This applies to Spanish representations of the Moroccan soldiers as well as Spanish treatment of the Moroccans soldiers.

In contrast, the image of the bloodthirsty Regulares raping and pillaging their way through Andalusia and Extremadura has not been forgotten. The savagery of the Moroccans remains imprinted on Spanish collective memory of the civil war, and an observer of contemporary Spanish society could say that negative representations of the Moor as aggressive, devious, untrustworthy, and lustful continue to circulate in Spanish culture. Despite the fact that Moroccans form one of the larger immigrant groups in Spain, these negative stereotypes endure despite repeated government initiatives to integrate North African immigrants. This is the reason why these historical representations of the Moorish Other should be deconstructed: because the discourse of the past continues to have a powerful influence on the social realities of the present.

${ }^{132}$ Madariaga, Los moros que trajo Franco, 342.

${ }^{133}$ Madariaga, Los moros que trajo Franco, 341. 